\title{
DECENTRALIZED SECURITY SYSTEMS IN HYBRID WAR CONDITIONS WITH AN EMPHASIS ON THE SECURITY SYSTEM IN BOSNIA AND HERZEGOVINA
}

\author{
Pregledni rad (Review Paper) \\ Received: 19 October 2021 \\ Accepted: 2 November 2021 \\ DOI: https://doi.org/10.37458/nstf.22.3.2
}

\section{Ph.D. Jerko Livaja*}

\begin{abstract}
Combining all hitherto known forms and methods of conventional and unconventional warfare, hybrid warfare is increasingly replacing classical military conflicts and is gradually changing into the primary form of realizing state interests, independently or within military-political alliances. No period in the history of human civilization has been marked by such an intensity of war conflicts as the last century. Apart from the two largest war conflicts in history, in which almost all countries of the world were involved, the last century was also marked by the Cold War.
\end{abstract}

Keywords: Bosnia and Herzegovina, security system, Hybrid threats, conflict, Hybrid war

* Phd.D. Jerko Livaja, employee of the Ministry of the Internal Affairs of the Herzegovina-Neretva County-Canton. Doctor of Law, Ph.D. acquired at the Faculty of Law, University of Mostar. He has been working in police agencies in Bosnia and Herzegovina since 1991. 
Introduction

Hybrid warfare perhaps fits best into Sun Tzu's philosophy of war, the essence of which is to defeat the enemy in the shortest possible time with as little material and technical resources, and lost human lives, as possible, both on the side of the attacker and the defender. ${ }^{1}$

No area of international relations between states, including the internal activities of state institutions, is covered by such changes and challenges as the area of security. Energy security, i.e. energy independence of a state, and economic stability and stability of the internal political and legal system with strengthening of institutional capacities of the state to respond to all security challenges, are imposed as priorities in the sphere of protection of state interests of modern state organizations.

Decentralized security systems are not unknown to modern society or the state. Such systems have their advantages and limitations. However, Bosnia and Herzegovina is specific in many ways in this regard. ${ }^{2}$

\section{History of global and regional conflict - a new balance of power}

The causes of war conflicts throughout history can be viewed from different aspects. In the past, the most common cause was conflict over a certain territory, i.e. for natural resources in a geographical area or due to unresolved relations around a

1 Sun Tzu points out that a skilled strategist defeats the enemy without war, conquers a city without a siege, defeats an enemy state without a protracted war. Sun Tzu, Umijeće ratovanja, edited, translated and foreword by John Minford, translated from English by Mirna Čubranić, Mozaik knjiga, Zagreb, 2021., p. 16.

2 Its political and legal framework is based on the peace agreement (Dayton Peace Agreement), in which one of its annexes (Annex IV) is the Constitution of Bosnia and Herzegovina. It is a state of two entities and three constituent peoples, with several levels of government and the High Representative for Bosnia and Herzegovina, whose political and legal position is above all those levels of government. Each level of government has its own constitution and constitutional competencies in certain matters, and they can be common or shared. Each level of government has its own independent law enforcement institutions. Cooperation between security agencies and law enforcement agencies in Bosnia and Herzegovina is based on the constitution, the law and mutual cooperation agreements. 
geographical area inhabited by an ethnic group living outside the home country. Conflicts over the unification of divided territories inhabited by the same ethnic group were not uncommon, same as war conflicts with a national sign resulting from the disintegration of complex multinational states.

For a long time throughout history, the balance of power has dominated political theories in preserving the state of peace in the world. Originating in European diplomacy, it was largely the basis of countless secret and public military-political alliances between countries on the European continent throughout history until the First World War. ${ }^{3}$

No period in the history of human civilization has been marked by such an intensity of war conflicts as the last century. Apart from the two largest war conflicts in history, in which almost all countries of the world were involved, the last century was also marked by the Cold War. The consequence of the confrontation was manifested in the Cold War, which lasted almost half a century, until the collapse of communism in the late 20th century.

Economic integration and political self-determination, the fundamental postulates of American foreign policy after World War II, were embedded in the foundations of European integration. ${ }^{4}$ The European rivalry between France and Germany turned into a strong European community that lasts to this day and that has outgrown economic integration and turned

3 Throughout much of European history, the guarantor of the balance of power on the European continent was first Richelieu's France and then England until the First World War. With the end of the First World War, the United States came on the scene, trying to change the world global order based on Wilson's political doctrine, trying to establish a global selfregulatory mechanism based on the global unification of states within the world political organization of the League of Nations. Experiences from this failed project were translated into the creation of the United Nations after World War II, the most successful project of the international community that still exists today.

4 The United States sought to direct the new international law towards the principles of political and national sovereignty, and economic integration in the conditions of the free market. In this sense, various forms of economic integration came to life only after the Second World War. However, the right of peoples to self-determination from initial general acceptance became a stumbling block in the development of international relations, mostly for ideological reasons both internationally and within multinational states, such as the first Yugoslavia. 
into a political organization sui generis. After World War II, Germany was accepted as an equal partner, without imposing blame on the German post-war government and the German people. In post-war Bosnia and Herzegovina, this was not done in the right way. The vision of a new Bosnia and Herzegovina has a future only in European integration, and before that it is necessary to accept and apply the experiences of European nations after the Second World War.

\section{Hybrid war - cause or mechanism for conflict resolution}

Along with the changes in the development of the state, there were changes in the organization of security systems. With the industrial revolution that enabled the development of new types of weapons, and especially the system of logistical support to the armed forces, the situation changed drastically. The Napoleonic Wars introduced a new doctrine in the previous system of warfare. World War I introduced the use of weapons of mass destruction, culminating in the use of nuclear weapons in World War II. The new world order created after World War II on the two opposing geopolitical options of the liberal US and the communist Soviet Union existed until the collapse of communism in the 1990s. The collapse of communism led to geopolitical shifts that manifested themselves in a series of wars, including those in the Balkans and our region in the 1990s. New powers are entering the world geopolitical scene, such as China, and the European Union as a special sui generis socioeconomic order, which includes Western European countries. The attack on the United States in September 2001 marked a turning point in war doctrines and theories. An organized attack by a terrorist organization on the heart of the United States, i.e. its symbols of power, showed all the vulnerability of American society, regardless of the prerogatives of the United States as the only superpower. After that event, things in the world changed radically. It is recognized that the use of targeted limited attacks achieves an effect of strategic proportions. Hybrid methods of intimidation and creating a state of insecurity are turning into mechanisms of social change. If we add to that the possibilities that come with the development of information technologies, the picture becomes complete, in terms of the ways and methods of conducting a hybrid war. War no longer implies the exclusive use of the armed forces, but the use of all 
available capacities to achieve the planned political goal. The advantages of hybrid warfare are especially evident in the application of international law of war, because hybrid attack or its methods that do not involve the direct use of armed forces, according to international convention law, neither allow the use of armed forces of the attacked side as in a classic military conflict, nor do they enable activation of defence mechanisms of military-political alliances ${ }^{5}$.

Although hybrid unarmed attack is not an integral part of the activation defence mechanism of Article 5 of the North Atlantic Treaty, the parties have accepted, at the political level, a broader interpretation of Article 5, in such a way that in cases of hybrid activities of both state and non-state actors, aimed at any of the members of NATO, they will take all measures and actions in terms of deterrence, assistance and protection of the attacked member. ${ }^{6}$

The nature of the wars in the former Yugoslavia has all the hallmarks of a hybrid conflict. The wars in the former Yugoslavia are the result of the unresolved national question of the first and second Yugoslavia. With the disintegration of the Socialist Federal Republic of Yugoslavia and the establishment of independent nation-states, national issues in this area were resolved. The exception is Bosnia and Herzegovina, which has

5 Article 5 of North Atlantic treaty provides:

The Parties agree that an armed attack against one or more of them in Europe or North America shall be considered an attack against them all and consequently they agree that, if such an armed attack occurs, each of them, in exercise of the right of individual or collective self-defence recognized by Article 51 of the Charter of the United Nations, will assist the Party or Parties so attacked by taking forthwith, individually and in concert with the other Parties, such action as it deems necessary, including the use of armed force, to restore and maintain the security of the North Atlantic area.

Any such armed attack and all measures taken as a result thereof shall immediately be reported to the Security Council. Such measures shall be terminated when the Security Council has taken the measures necessary to restore and maintain international peace and security.

6 From one of the conclusions of the summit in Brussels published by the Heads of State and Government of the North Atlantic Council in Brussels on June $14^{\text {th }}$, 2021, North Atlantic Treaty Organization (NATO-OTAN), available at: https://www.nato.int/cps/en/natohq/news_185000.htm (October $3^{\text {rd }}, 2021$ ) 
been established as a multinational state, still struggling with the legacy of the past and an incomplete solution to interethnic relations within the Dayton political and legal framework. Due to this situation, Bosnia and Herzegovina is particularly vulnerable to various forms of hybrid war threat.

\section{Political and legal framework of Bosnia and Herzegovina - cause or resolution of ethnic conflict}

The Dayton Peace Agreement is the alpha and omega of the political and legal system of today's Bosnia and Herzegovina. Its nature is twofold, on the one hand it is a mechanism for ending war conflicts in Bosnia and Herzegovina, and on the other hand it is a tool for establishing lasting peace. The Dayton Peace Agreement was supposed to be a requiem for pre-war and war nationalist policies in Bosnia and Herzegovina. However, it turned out that the existing political and legal framework of Bosnia and Herzegovina did not solve the causes of the war in Bosnia and Herzegovina, although its goal was precisely to introduce Bosnian and Herzegovinian society through the transition to the society of European nations. The 25-year transition experience so far shows just the opposite, at times with so much political charge as if it were the early 1990s, rather than a 25 -year transition gap.

In the administrative sense, Bosnia and Herzegovina is organized as a state of two entities and one district, with one of the entities being a federation of counties/cantons. Each of these administrative units is regulated as a separate level of government with its own and shared constitutional competencies. Unlike the Dayton constitutional solution at the level of the state of Bosnia and Herzegovina, where it is explicitly prescribed that everything that is not placed under the competence of the state falls under the competence of the entities, at the lower level of government in the Federation of Bosnia and Herzegovina this matter is constitutionally regulated through a system of joint and exclusive competencies of the Federation of Bosnia and Herzegovina and counties/cantons. This is not the case in Republika Srpska, as it is organized as one administrative unit. The Statute of the Brčko District of Bosnia and Herzegovina establishes the authority of the Brčko District of Bosnia and Herzegovina in the area of the district. 
The security system in Bosnia and Herzegovina is highly decentralized. It is a reflection of the constitutional order of Bosnia and Herzegovina and its territorial structure. Internal security rests on law enforcement agencies, while the guarantor of external security is the international community. Decentralized security systems are not necessarily a security flaw in terms of weaknesses in functioning at critical moments, especially in hybrid attack conditions. When it comes to the security system of Bosnia and Herzegovina, the same is in line with its administrative system. It operates on the basis of the constitutional competencies of each of the levels of government and within the given legal framework. Many things important for the successful functioning of the security system, i.e. the execution of legal competencies, are resolved by mutual agreements, which regulate or elaborate in more detail those issues that do not conflict with their constitutional and legal competencies.

\section{Decentralized security system of Bosnia and Herzegovina - institutional security challenge}

The advantages of decentralized states (federations, confederations) and ultimately regional alliances, especially those sui generis such as the European Union, are reflected directly in the construction and functioning of society and security systems. Of course, there are differences in the organization of decentralized security systems within a state community, a regional international organization such as the European Union or military-political alliances such as NATO. The basic postulates of security policy of all three are not diametrically different.

In the decentralized legal system of Bosnia and Herzegovina, conflicts of jurisdiction of a positive and negative nature are possible. ${ }^{7}$ Agreements on mutual cooperation between law

Examples from practice best reflect such a situation. Such is the case, for example, with the murder of two soldiers belonging to the Bosnia and Herzegovina Armed Forces in Rajlovac near Sarajevo in 2015. Bearing in mind that they were members of a state institution, whose murder could be characterized as a terrorist act, and everything happened in the area of jurisdiction of Sarajevo Canton, all three levels of government (state, entity 
enforcement agencies are not uncommon in resolving issues of importance for the work and lawful conduct of agencies within their jurisdiction in Bosnia and Herzegovina. They are a reflection of the autonomous work and activities of security institutions with a cohesive sign. The agreements address those issues concerning their more efficient and closer cooperation. Similarly, in the European Union, through the agreed concept of different speeds of integration, it is possible for members to build special cohesion relations within the Union by accepting and contracting closer forms of cooperation in certain matters.

Encouraging independence and integration as a model rule for strengthening the security sector in Bosnia and Herzegovina comes down to further building and strengthening the capacity of security agencies in Bosnia and Herzegovina, on the principle of simultaneously encouraging independence and integration in terms of creating conditions for independent and joint work, in accordance with constitutional principles of common and shared competencies between individual levels of government in Bosnia and Herzegovina (state, entity, county/canton and local). Such an approach in the current conditions is imposed as the only logical solution, given the permanent political crisis, the causes of which are to some extent in the wrong approach to building a Bosnian and Herzegovinian society in this regard. Of course, this approach requires the support of the international factor present in Bosnia and Herzegovina, because previous experiences in imposing final solutions and attempts at centralization show the opposite effect. Ultimately, isn't the simultaneous promotion of independence and integration from the experience of European integration an applicable model rule for the organization of Bosnian and Herzegovinian society? Having in mind the Dayton political and legal framework, such an approach would create a more functional state and its institutions, while on the other hand, the risk of a hybrid war threat would be reduced.

- federal and canton) could establish jurisdiction in the same matter. Although there is a legal procedure for resolving this issue in cases of conflicts of jurisdiction, mutual agreements on cooperation between law enforcement agencies are also very helpful. 


\section{Conclusion:}

Bosnia and Herzegovina as a state is the result of a compromise between the warring parties in this area, and the current geopolitical relations of the great powers led by the United States, translated into the provisions of the Dayton Peace Agreement. The geopolitical rearrangements of the current policies of the peoples of Bosnia and Herzegovina after the war within the Dayton Constitution could be reduced to the following: Bosniak national policy aims to transform Bosnia and Herzegovina into a Bosniak nation state, and alongside to transform Federation of Bosnia and Herzegovina (common entity of Bosniaks and Croats) into a Bosniak entity to the detriment of the rights of the Croat people; the national policy of Croats in Bosnia and Herzegovina is reduced to the protection and realization of the full constitutivity of Croats in the territory of Bosnia and Herzegovina; the national policy of the Serbian people in Bosnia and Herzegovina comes down to strengthening the entity of the Republika Srpska in the sense of the legal state. A compromise between these three national policies is the key to resolving the current political crisis and the path to a better future. In this regard, the European Union must be aware that Bosnia and Herzegovina needs to have a different, specially tailored path towards European integration. Insisting on reforms according to the civic principle (majority rule - one man one vote), without resolving the national question for all three peoples within Bosnia and Herzegovina, sows the seeds of new conflicts in the future.

The migrant crisis and the state of the coronavirus pandemic as current threats in terms of the hybrid war threat are among the most acute problems of today, especially in Southeast Europe, to which Bosnia and Herzegovina geographically belongs. ${ }^{8}$

8 The issue of population migration from precarious war zones in Asia and Africa, both legal and illegal, is increasingly emerging as a security risk for orderly Western democracies. In a special way, this refers to today's ubiquitous problem of illegal migration in our region and the European Union. The danger of import terrorism through the migrant population is becoming a real factor in causing internal instability in the member states of the European Union and the Balkan states. This is reflected in a special way in Bosnia and Herzegovina with a very pronounced unstable internal political order, which in itself is a challenge, let alone in the conditions of residence of a large number of migrants, regardless of the fact that Bosnia 
These security challenges, combined with the current political crisis caused by the collapse of Croat constituencies, and the dispute over the political and legal position of the new High Representative for Bosnia and Herzegovina, are the ideal basis for various hybrid war conflicts.

Despite the prominent issues of functioning of Bosnia and Herzegovina in the political, legal, economic and security sense, Bosnia and Herzegovina within the Dayton political and legal framework has a future, if first its political discourse returns to the original Dayton principles, primarily with the aim to achieve full constitutionality of Bosnia and Herzegovina people on the territory of Bosnia and Herzegovina and to abandon the civic concept of state organization, ${ }^{9}$ and then to strengthen all institutional capacities on the premises of decentralization, with continuous strengthening of the economy and free market, and protection of human rights and fundamental freedoms as necessary preconditions for society development and its inclusion in Society of European Nations - European Union. Complete reconciliation among the peoples of Bosnia and Herzegovina as a precondition for the successful transition of Bosnian and Herzegovinian society to modern European society cannot be skipped, by building civil society as the most important civilizational achievement of Western democracy, without protecting the national interests of Bosnian and Herzegovinian peoples on the principle of their complete constituency on the territory of Bosnia and Herzegovina. Ultimately, building such a model, despite all its complexity and difficulties, should be

and Herzegovina is treated as a transit area for migrants. on the road to the European Union.

9 The Dayton legal framework is based on the equality and constitutivity of the peoples of Bosnia and Herzegovina (Bosniaks, Croats and Serbs). The principle of the constitutivity of the people in Bosnia and Herzegovina is the overriding principle of the constitutional order of Bosnia and Herzegovina, which was also determined by the Constitutional Court of Bosnia and Herzegovina in its decision in case number $U$ 5/98 (Official Gazette of Bosnia and Herzegovina, No. 11/00, April 1 $17^{\text {th }}$, 2000, p. 105114). However, constitutivity in the Dayton constitutional sense is not a mere legalistic principle, but it implies a legitimate representation of the peoples of Bosnia and Herzegovina and as such was also confirmed by the decision of the Constitutional Court of Bosnia and Herzegovina in case number $U$ 23/14 (Official Gazette of Bosnia and Herzegovina, No. 1/17, January $6^{\text {th }}, 2017$, p. 29-41). 
perceived as an obligation of all political actors, including the international community.

1. Sun Tzu, Umijeće ratovanja, edited, translated and foreword by John Minford, translated from English by Mirna Čubranić, Mozaik knjiga, Zagreb, 2021.

2. North Atlantic Treaty Organization (NATO-OTAN), Brussels Summit Communiqué, Issued by the Heads of State and Government participating in the meeting of the North Atlantic Council in Brussels 14 June 2021, available at: https://www.nato.int/cps/en/natohq/news_185000.htm (October $3^{\text {rd }}, 2021$ )

3. The decision of the Constitutional Court of Bosnia and Herzegovina, case number U 5/98, Official Gazette of Bosnia and Herzegovina, No. $11 / 00$, April $17^{\text {th }}, 2000$, p. 105-114.

4. The decision of the Constitutional Court of Bosnia and Herzegovina, case number $U$ 23/14, Official Gazette of Bosnia and Herzegovina, No. $1 / 17$, January $6^{\text {th }}, 2017$, p. 29-41. 


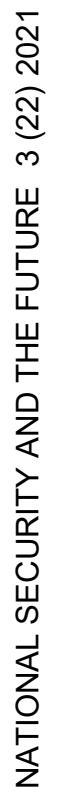

